\title{
PENDEKATAN PSIKONEUROIMUNOLOGI
}

\author{
Adnil Edwin Nurdin \\ Dosen Psikiatri Fakultas Kedokteran Universitas Andalas \\ dan Program S2, S3 Biomedis Universitas Andalas \\ E-mail : adnilerwinnurdin@yahoo.com
}

\begin{abstract}
Abstrak
Psikoneuroimunologi merupakan konsep terintegrasi mengenai fungsi regulasi-imun untuk mempertahankan homeostasis. Untuk mempertahankan homeostasis, sistem imun berintegrasi dengan proses psikofisiologik otak, dan karena itu mempengaruhi dan dipengaruhi otak. Melalui pendekatan ini telah mulai dipahami mekanisme interaksi antara perilaku, sistem saraf, sistem endokrin, dan fungsi imun. Komponen perilaku dari interaksi ini melibatkan kondisioning Pavlov pada peningkatan maupun penekanan antibodi dan respon imun seluler. Kondisioning ini berekspresi sebagai efek pengalaman stress terhadap fungsi imun. Selanjutnya diketahui bahwa mekanisme terintegrasi ini berlangsung dalam ritme yang berkaitan dengan ritme lingkungan seperti ritme Sirkadian. Respon stress berkelanjutan berekspresi sebagai sindroma adaptasi umum. Sebagai respon akut dimulai dengan initial brief alarm reaction. Dalam tahap ini peningkatan sekresi cortisol pada aksis Hypothalamic-Pituitary-Adrenal (HPA) menimbulkan supresi pada sebagian besar fungsi imun dan peningkatan aktifitas sistem simpatis. Bila stress tidak dapat diatasi secara efektif, tahap kedua prolonged resistance period akan dimulai, dimana aktivasi aksis HPA akan menurun tetapi tidak pernah mencapai kondisi basal. Kegagalan berkelanjutan untuk mengatasi stress akan berakhir pada terminal stage of exhaustion and death. Aplikasi medis psikoneuroimunologi akan meningkatkan efektifitas terapi penyakit keganasan, gangguan kardiovaskular, penyakit infeksi, trauma fisik, transplantasi, dan gangguan jiwa.

Kata kunci: aksis HPA, antibodi, aplikasi medis, cortisol, homeostasis, melawan atau lari, otak, Pavlov, perilaku, psikofisiologik, psikoneuroimunologi, sindroma adaptasi umum, sistem imun, sistem LS-NA, respon stress, ritme Sirkadian
\end{abstract}

\begin{abstract}
Psychoneuroimmunology is an integrated concept of immune-regulatory function. To maintain homeostasis, the immune system is integrated with psychophysiological processes of the brain, and is therefore influenced by and capable of influencing the brain. Mechanism of interaction among behavior, neural, endocrine, and immune functions in adaptation to environmental stressors have come to light. The behavioral components of this interaction involve the Pavlov conditioning both in the enhancement and supression of antibody-and cellmediated immune responses. This conditioning expressed as effects of stressful experiences on immune function. This integrated mechanism operated in a rhythm
\end{abstract}


related to environmental rhythm such as Circadian rhythm. Prolonged stress response will be expressed as general adaptation syndrome. As an acute response it will begin with initial brief alarm reaction. In this stage increased cortisol secretion in Hypothalamic-pituitary-adrenal (HPA) axis resulted in supression of main immune function and arousal of sympathetic system If the stress can not be coped effectivelly, a second stage of prolonged resistance period will begin, in which HPA axis activation will be decreased but never reach the basal condition. Continued failure to cope with the stress will end in terminal stage of exhaustion and death.

Medical application of psychoimmunology can enchance the effectivity of the treatment of malignancy, cardiovascular disorder, infectious diseases, physical trauma, transplantation, and mental disorder.

Key word : antibody, behavioral, brain, Circadian rhythm, cortisol, fight or flight, general adaptation syndrome, homeostasis, HPA axis, immune system, LC-NA system, medical application, Pavlov, psychoneuroimmunology, psychophysiological, stress responses 


\section{Pendahuluan}

Peradaban membuat kita hidup dalam kondisi stres psikologis dan fisiologik. Mengacu pada definisi yang dikemukakan pertama kali oleh Hans Selye tahun 1930: stress adalah kondisi yang merupakan konsekwensi psikobiologik dari kegagalan organisme hidup untuk merespon secara berhasil guna setiap ancaman fisik ataupun emosional, baik yang merupakan ancaman aktual maupun imajinasi, yang berperan sebagai stresor. ${ }^{(\mathbf{1 , 2})}$

Stresor untuk organisme kompleks multiseluler seperti manusia, didefinisikan sebagai stimulus yang oleh otak dianggap ancaman dan menimbulkan keadaan disforik, serta fisiologis meningkatkan produksi noradrenalin dan adrenalin untuk mekanisme melawan atau lari. Stresor itu mencakup rasa nyeri, persepsi ancaman, dan "keterpaksaan" melakukan aktifitas yang tidak mengikuti ritme fisiologik seperti ritme Sirkadian. Semua stresor ini dipersepsi oleh otak sebagai kondisi disforik yang menimbulkan kondisi stres dan mempengaruhi semua fungsi homeostasis mulai dari kardiovaskular sampai fungsi imun. Selanjutnya ditemukan bahwa sitokin sebagai bagian sistem imun ternyata juga mengendalikan neuron dan sel glia otak. ${ }^{(3-6)}$

Berdasarkan peran otak tersebut, psikoneuroimunologi mengemukakan premise major yaitu otak dan sistem imun merupakan satu kesatuan homeostasis melalui fungsi psikobiologik. $^{(\mathbf{1}, \mathbf{2})}$

\section{Substrat biologik respon stress}

Respon stress terjadi bila seseorang menghadapi stimulus yang dianggapnya merupakan ancaman bahaya sebagai stresor. Karena itu respon stress selalu terjadi dalam tiga etape yaitu:
1. Etape persepsi stresor

2. Etape respon stress

3. Etape persepsi keberhasilan respon

Setiap etape ini mempunyai substrat biologik utama. ${ }^{(7,8)}$

\section{Etape persepsi stresor}

Substrat biologiknya ialah korteks prefrontalis (KPF), nukleus amigdala, dan hipocampus, serta sistem reward mesolimbik yang terdiri dari area tegmental ventralis (ATV), nukleus akumben (NAk). Sedangkan neurotransmiter yang berperan ialah GABA (gamma-aminobutiric acid), hormon katekolamin yaitu dopamin (DA), adrenalin (A), dan noradrenalin (NA), serotonin (5-HT) serta neuropeptida $\mathrm{S}$.

Apabila terjadi stimulus dari luar, maka KPF akan menilai apakah stimulus itu berbahaya atau tidak dengan menggunakan informasi yang disimpan dalam hipocampus (memori dari pelajaran atau pengalaman lalu). Bila dinilai berbahaya, maka neurotransmiter penghambat GABA dihambat, tercetus sinyal ke amigdala yang akan mencetuskan muatan emosional dari respon stress tergantung penilaian. Bila menakutkan respon lari, bila memarahkan respon melawan. Keduanya disebut respon melawan atau lari (fight or flight). Apapun responnya, terjadi reaksi cascade dimulai peningkatan sekresi serotonin, diikuti peningkatan sekresi dopamin, yang diikuti lagi oleh peningkatan adrenalin sehingga terjadi emosi disforik (tidak nyaman). Proses berikutnya adalah etape respon stress. ${ }^{(9,10)}$

\section{Etape respon stress}

Substrat biologiknya yang telah diketahui ialah sistem lokus Sereleus (LS)Noradrenalin (NA), aksis hypothalamic-pituitary-adrenal (HPA) yang juga disebut lengkung imun-otak, dan 
kelenjar pineal yang berkaitan dengan ritme Sirkadian. Sedangkan neurotransmiter yang berperan ialah A, NA, glucocorticoid dengan cortisol sebagai hormon stress utama, serta melatonin yang berkaitan dengan ritme Sirkadian. Etape ini disebut juga Sindroma Adaptasi Umum (SAU) pada fase initial brief alarm reaction. Etape ini sangat mempengaruhi semua sistem homeostasis yang secara umum mengalami peningkatan, kecuali sistem imun yang secara umum mengalami supresi. Peningkatan NA segera diikuti peningkatan A. Terjadi adrenalin rush, yang memobilisasi semua sistem energi tubuh untuk reaksi melawan atau lari. Adrenalin rush menyebabkan jumlah free floating DA meningkat. Kita sampai ke point of no return dimana perilaku melawan atau lari Fungsi otak dalam etape ini mengalami disinhibisi sehingga perilaku melawan atau lari terjadi secara "otomatis" tanpa pengendalian. ${ }^{(9,10)}$

\section{Etape keberhasilan respon}

Substrat biologiknya ialah KPF, dan sistem reward mesolimbik. Sedangkan neurotransmiter yang paling berperan ialah DA sebagai neurotransmiter kenikmatan.

Bila perilaku melawan atau lari segera menyelesaikan masalah (hanya terjadi pada tingkat peradaban pemburupengembara), maka kita masuk ke respon relaksasi. Dalam hal ini DA terikat pada reseptor $\mathrm{DRD}_{2}$ di NAk, timbul perasaan nyaman, adrenalin dan noradrenalin menurun, glucocorticoid menurun, semua fungsi homeostasis turun kembali ketingkat basal. ${ }^{(\mathbf{9 , 1 0})}$

Bagaimana bila respon stress akut gagal mengatasi kondisi stress?

Artinya kita selalu dalam kondisi stress akut yang memobilisasi fungsi homeostasis sehingga kita selalu dalam reaksi melawan atau lari. Tentu saja suatu saat kita akan kehabisan energi dan terjadi kerusakan pada hampir semua sistem organ yang mengganggu homeostasis.

Untuk memahami proses yang terjadi kita akan membahas Sindroma Adaptasi Umum sebagai respon fisiologik stress

\section{Sindroma Adaptasi Umum (SAU) sebagai respon fisiologik stress}

Melalui penelitian selama 10 tahun pada berbagai hewan, Selye pada tahun 1974 mendeskripsikan tiga tingkat adaptasi terhadap stress berkelanjutan (prolonged stres) yang disebut Sindroma Adaptasi Umum (SAU). Dimulai dengan initial brief alarm reaction, diikuti periode resistensi berlanjut (prolonged resistance period) dan diakhiri tingkat terminal kelelahan (terminal stage of exhaustion and death). ${ }^{(11,12)}$

Riset glucocorticoid menemukan pada initial brief alarm reaction terjadi peningkatan tajam kadar glucocorticoid darah. Selanjutnya pada periode resistensi ketajaman peningkatan mulai mendatar, tetapi masih lebih tinggi dari pada kadar basal glucocortikoid. Dengan berlanjutnya stress, pada suatu titik tiba-tiba kadar glucocorticoid menurun pada tingkat terminal kelelahan, yang diikuti kematian. Berdasarkan ini, pengukuran kadar glucocorticoid darah dipakai sebagai metode deteksi tingkat stress yang dapat membahayakan kehidupan. ${ }^{(11,12)}$

Pert dkk pada tahun 1985 menemukan bahwa neuropeptida dan neuro-transmiter (yang berperan pada pengendalian emosi) didapatkan pada dinding sel neuron otak dan dinding sel pengendali sistem imun serta dinding sel berbagai organ endokrin. Temuan ini mengesankan saling keterkaitan fungsi emosi yang dikendalikan susu- 
nan saraf pusat dengan fungsi imun yang merupakan sistem pertahanan tubuh serta sistem endokrin yang berkaitan dengan homeostasis. ${ }^{(\mathbf{1 1}, \mathbf{1 2})}$

Dapat dideduksi bahwa terdapat mekanisme yang mendasari perubahan respon imun yang dicetuskan fungsi mental ataupun perubahan fungsi mental yang dicetuskan respon imun. Mekanisme coping terhadap stress mental mempengaruhi respon imun dalam upaya mempertahankan homeostasis sampai level molekuler. Manifestasi organobiologik SAU ialah hipertrofi kelenjar adrenal dan atrofi thymus, limpa dan jaringan limfoid, serta ulserasi gaster. ${ }^{(11,12}$

Berdasarkan konsep diatas, psikoneuroimunologi mengajukan premise dasar; otak merupakan bagian integral dari sistem imun sebagai salah satu parameter homeostasis. ${ }^{(\mathbf{1 1}, \mathbf{1 2})}$

\section{Initial brief alarm reaction sebagai respon terhadap stress akut}

Pada initial brief alarm reaction terjadi peningkatan tajam kadar glucocorticoid dalam darah akibat aktifitas otak melalui aksis hypothalamic-pituitary-adrenal (HPA), selanjutnya melalui reaksi cascade akan terjadi aktifitas amigdala dan hippocampus, sistem kardiovaskuler, sistem respirasi, dan sirkulasi darah, sistem pencernaan, sistem imun, mukosa, dan kulit secara sistematis sebagai berikut $:^{(11-15)}$

\section{Aktifitas otak pada initial brief alarm reaction}

- Aktivasi aksis HypothalamicPituitary-Adrenal (HPA)

Merupakan respon kilat terhadap stresor yang dipersepsi berbahaya, seperti menghadapi binatang buas atau gempa bumi.

- Aktivasi sistem Lokus Sereleus (LS)-Noradrenalin (NA)
- Pelepasan hormone steroid dan hormone stress utama cortisol.

Aksis HPA meningkatkan produksi dan pelepasan glucocorticoid termasuk hormone stress utama cortisol. Selanjutnya cortisol memobilisasi aktifitas hampir semua sistem homeostasis seperti kardiovaskular, respirasi, pencernaan, metabolisme, sistem imun, kulit dan mukosa, dalam persiapan reaksi melawan atau lari (fight or flight).

- Pelepasan katekolamin

Aksis HPA melepaskan hormon katekolamin yang juga berperan sebagai neurotransmitter, yaitu dopamin (DA), adrenalin (A), dan noradrenalin (NA).

- Aktivasi amigdala

Katekolamin mengaktifkan nucleus amigdala yang mencetuskan respon emosional terhadap stressor, misalnya takut terhadap gempa, atau marah kepada musuh.

- Pelepasan neuropeptida $S$

Otak melepaskan neuropeptida $\mathrm{S}$, suatu mikro protein yang memodulasi stress dengan menekan keinginan tidur, meningkatkan kewaspadaan dan perasaan kuatir. Akibatnya timbul keinginan urgen untuk perilaku melawan atau lari (fight or flight).

- Efek pencetus perilaku instinktual

Dalam keadaan stress akut, katekolamin menekan secara sekuensial fungsi korteks prefrontalis yang berkaitan dengan memori jangka pendek, inhibisi, konsentrasi, dan pola pikir rasional. Sekuens penekanan proses mental ini memung- 
kinkan seseorang bereaksi cepat untuk melawan atau lari secara individual tanpa memikirkan kewajiban sosial dan norma. Karena memori jangka pendek dan inhibisi ditekan, satusatunya fungsi sosial yang melekat adalah ikatan pada keluarga langsung.

- Efek pada memori jangka panjang

Pada saat yang sama, katekolamin sebagai neurotransmiter member sinyal ke hippocampus untuk merekam pengalaman stresor yang padat emosi ini sebagai memori jangka panjang. Pada masa prasejarah, kerja otak ini sangat vital untuk kelestarian karena memori jangka panjang tentang beragam stimulus berbahaya ini sangat menentukan untuk menghindari ancaman berbahaya ini di masa depan.

- Penekanan fungsi "rem" perilaku otak

Dalam kondisi stress akut, neuron otak "dengan sengaja" meng interpretasi sinyal kimiawi neurotransmiter untuk inhibisi secara salah. Sinyal "off" justru diinterpretasi "on", sehingga "rem" perilaku tidak berfungsi. Terjadi disinhibisi total perilaku dengan patogenesis yang sama dengan penggunaan cannabis. Seseorang yang merasa terancam akan melakukan perilaku apapun dalam upaya melawan atau lari.

\section{Respon imun terhadap stress akut}

- Paradox cortisol

Efek konfrontasi dengan stresor pada sistem imun analog dengan mobilisasi pasukan yang dikonsentrasikan hanya pada area yang terancam invasi. Peningkatan cortisol pada aksis HPA menekan fungsi imun pada sebagian sistem imun, sehingga sel imun spesifik seperti leukosit dan sitokin mengalami reposisi. Sel tersebut dikirimkan ke bagian tubuh yang paling berisiko luka atau terkena infeksi, seperti kulit dan kelenjar limfe. Tetapi secara umum terjadi penekanan fungsi imun yang disebut paradox cortisol yang bersifat vital karena semua proses homeostasis dimobilisasi untuk persiapan reaksi melawan atau lari.

- Peningkatan aktifitas sitokin proinflamatori

Substrat biomolekuler yang meningkat pada respon stress ialah molekul sitokin pro-inflamatori, terdiri dari; interleukin-1 (IL-1), interleukin-2 (IL-2), interleukin-6 (IL-6), interleukin-10 (IL-10), interleukin-12 (IL-12), interferon-gamma (IFNGamma) dan tumor necrosis factor alpha (TNF- $\alpha)$.

Sel imun makrofag yang merupakan sel pertama tiba pada lokasi infeksi apapun, memproduksi molekul-molekul diatas ini.

- Respon sakit

Penelitian membuktikan bahwa molekul sitokin pro-inflamatori ini berfungsi langsung dalam otak dengan pembentukan mikroglia dan astrosit (sel glia) untuk mencetuskan respon sakit (sickness response). Sitokin juga diproduksi lokal dalam otak, terutama pada hipotalamus. Karena itu sitokin 
memberi kontribusi pada efek perilaku akibat stress fisik dan mental.

- Penekanan T helper (Th1) dan peningkatan $\mathrm{T}$ helper (Th2)

Terjadi disregulasi neurohormon yang berekspresi dengan supresi respon imun anti tumor.

- Mediasi sitokin pada respon stress dan inflamatori melalui otak.

Sitokin memediasi dan mengendalikan respon imun pada stress dan proses inflamatori. Interaksi sangat kompleks terjadi antara sitokin, inflamasi, dan respon adaptif dalam mempertahankan homeostasis. Seperti juga respon stress, reaksi inflamasi sangat penting untuk survival. Reaksi inflamasi sistemik menyebabkan stimulasi terhadap empat fungsi utama yaitu: Reaksi fase akut, Sindroma sakit, Nyeri, Respon stress.

Keempat fungsi utama ini dimediasi oleh aksis HPA dan sistem simpatis. Dalam hal ini penyakit seperti alergi, gangguan autoimun, infeksi kronik, dan sepsis mempunyai karakteristik adanya disregulasi dari keseimbangan sitokin pro-inflamatori terhadap antiinflamatori dan antara $\mathrm{T}$ helper (Th1) terhadap (Th2).

\section{Respon stress akut pada mukosa}

- Cairan tubuh dialihkan dari lokasi non-essensiel seperti mulut dan tenggorokan. Karena itu mulut dan tenggorokan menjadi kering.

\section{Respon stress akut pada kulit}

- Efek stress akut memindahkan aliran darah dari kulit untuk mendukung jaringan otot lurik dan otot jantung. Hal ini cukup vital karena bila dalam reaksi melawan atau lari terjadi luka, maka perdarahan yang terjadi tidak begitu hebat.

\section{Respon stress akut terhadap metabolisme \\ - Reaksi fosforilasi dalam siklus Kreb akan meningkat untuk mencukupi kebutuhan energi yang meningkat.}

\section{Respon stress akut terhadap fungsi digestivus \\ - Stress akut akan menghambat pencernaan.}

Bila stressor tidak teratasi, maka kondisi stress berlanjut menjadi stress kronik, respon menjadi periode resistensi berlanjut (prolonged resistance period). ${ }^{(16-18)}$

\section{Periode resistensi berlanjut (prolonged resistance period)}

Dalam periode ini, kondisi stress masih dapat diatasi melalui mekanisme mental dengan "membudayakan" pemahaman dan perasaan bahwa stimulus yang dianggap stresor itu bila tidak dapat diatasi dapat dianggap "bukan stresor", atau setidaktidaknya dapat ditolerir. ${ }^{(\mathbf{1 9}, \mathbf{2 0})}$

\section{Bagaimana bila mekanisme mental gagal?}

Kegagalan mekanisme mental pada periode resistensi berlanjut, akan berdampak buruk terhadap semua sistem fisiologik yang dapat mencetuskan penyakit pada individu yang memiliki kerentanan genetik untuk penyakit tersebut, atau memperburuk prognosis penyakit yang sudah ada, atau menghambat proses terapi penyakit. Kegagalan ini berakhir pada tingkat terminal kelelahan (terminal stage of exhaustion and death). ${ }^{(\mathbf{1 9}, \mathbf{2 0})}$ 


\section{Tingkat terminal kelelahan (terminal stage of exhaustion and death)}

Kelelahan yang berakhir dengan kematian akan terjadi melalui proses berikut :(19-23)

\section{Penyakit dengan peningkatan sitokin pro-inflamatori}

- Penelitian terbaru memperlihatkan bahwa peningkatan sitokin pro-inflamatoriterjadi pada depresi, mania, dan gangguan bipolar, seperti juga pada hipersensitivitas, penyakit auto-imun dan infeksi kronik.

\section{Disregulasi neurohormon berlanjut}

- Sekresi kronik hormon stress glucocorticoid (GCs) dan katekolamin, akibat penyakit, akan menekan efek neurotransmiter seperti serotonin (5-HT), noradrenalin (NA), dan dopamin (DA), atau reseptornya di otak. Akibatnya terjadi disregulasi neurohormon.

Dalam stimulasi, NA dilepaskan dari terminal saraf simpatis didalam organ.

Penekanan terhadap aktifitas sel limfoid pada infeksi

- Pada infeksi, sel imun target mengekspresikan adrenoreceptor. Melalui stimulasi reseptor ini oleh NA yang dilepaskan di lokal, atau oleh katekolamin yang beredar seperti adrenalin, akan terjadi efek penekanan terhadap lalu lintas limfosit. Selanjutnya terjadi penekanan terhadap lalu lintas, proliferasi, dan aktivitas fungsional dari beragam sel limfoid. Infeksi tidak dapat diatasi.

\section{Fasilitasi inflamasi sistemik}

- Glucocorticoid juga menginhibisi sekresi selanjutnya corticotropin-releasing

hormone dari hipotalamus dan ACTH dari pituitari melalui mekanisme feedback negative. Hormon stress dalam kondisi tertentu juga akan mengfasilitasi inflamasi melalui induksi dari jaras pengsinyalan dan melalui aktivasi corticotropinreleasing hormone $(\mathrm{CRH})$.

- Abnormalitas ini dan kegagalan dari sistem adaptif untuk mengatasi inflamasi mempengaruhi secara negatif parameter perilaku, kualitas hidup, metabolisme, dan sistem kardiovaskular. Kegagalan ini akan berkembang kepada suatu feedback anti-inflamasi sistemik dan/atau hiperaktifitas dari faktor pro-inflamasi lokal yang memberi kontribusi pada patogenesis penyakit.

\section{Perburukan penyakit neurogeneratif}

- Aktivasi sistemik maupun aktivasi neuro-inflamasi dan neuroimun berperan pada etiologi berbagai gangguan neurogeneratif seperti penyakit Parkinson, Alzheimer, multiple sclerosis, nyeri, dan demensia yang berkaitan dengan AIDS.

\section{Peran kelenjar pineal berkaitan dengan ritme Sirkadian pada respon imun}

Kelenjar pineal memproduksi melatonin yang bersifat meningkatkan fungsi imun. Melatonin berperan pada fungsi imun karena akan berikatan dengan reseptor afinitas tinggi ((MT1 dan MT2) yang diekspresikan pada sel imunokompeten. ${ }^{(24,25)}$

Dalam penelitian, melatonin meningkatkan produksi sitokin, sehingga dapat menghambat proses perburukan dari AIDS. Sifat mening- 
katkan fungsi imun ini memungkinkan melatonin dapat digunakan terhadap infeksi viral, HIV, infeksi kuman, dan pengobatan kanker. ${ }^{(25-27)}$

Melatonin endogen pada limfosit manusia berkaitan dengan produksi interleukin-2 (IL-2) dan ekspresi reseptor IL-2. Sifat ini karena melatonin terlibat dalam ekspansi klonal antigen-stimulated limfosit $\mathrm{T}$ pada manusia. Melatonin bersifat imunostimulator bila digunakan bersama kalsium, karena itu digunakan sebagai terapi adjuvant pada beberapa protokol klinik. ${ }^{(25,28)}$

Tetapi sifat meningkatkan aktifitas sistem imun tersebut dapat memperberat gangguan autoimun. Malahan telah diketahui bahwa produksi melatonin pada penderita artritis rematoid lebih tinggi dibanding kontrol sehat. ${ }^{(26)}$ Sekresi melatonin hanya terjadi pada kegelapan total menurut ritme Sirkadian yang menentukan aktifitas fungsi mental dan fisiologik menurut jam sudut matahari lokal (lihat gambar 1).

\section{Parameter mental, fisiologik dan imunologik dalam ritme Sirkadian}

Hampir semua fungsi mental dan fisiologik termasuk fungsi imun dan fungsi seksual dikendalikan secara ritmik oleh ritme Sirkadian. Dalam hal ini, hormon melatonin yang berperan penting pada fungsi imun sekresinya dimulai pada kegelapan total malam (jam 21.00) saat sinar matahari langsung dan berpendar tidak ada lagi secara total. Sedangkan jam 07.30, saat sinar matahari mulai menerangi secara langsung keseluruhan belahan bumi siang, sekresi melatonin berhenti (lihat gambar 1).

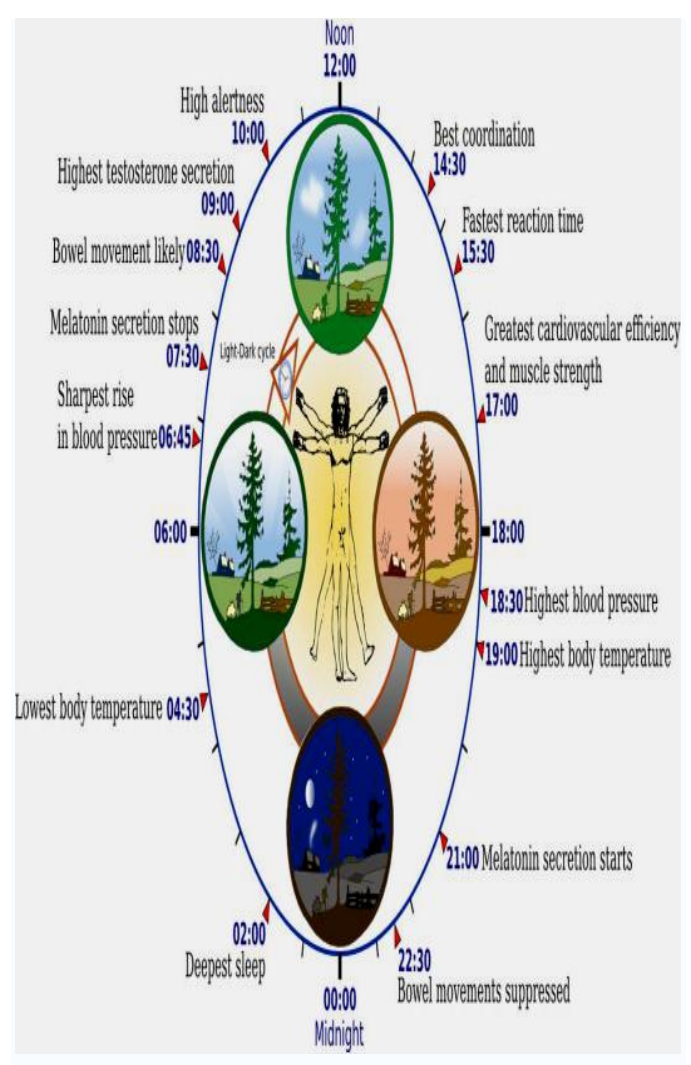

Gambar 1. Parameter mental, fisiologik dan imunologik dalam ritme Sirkadian. Sumber. Berczi and Szentivanyi (2003) NeuroImmune Biology, Elsevier.

\section{Ringkasan}

1. Semua orang pernah mengalami stress.

2. Stress akut mencetuskan perubahan fisiologik yang cepat diseluruh tubuh. Aktifitas hampir semua sistem fisiologik dimobilisasi untuk menghadapi stimulus yang dianggap berbahaya sebagai stresor.

3. Stress kronik harus ditanggulangi karena dapat mengakibatkan kerusakan fisik dan mental. 
4. Kondisi stress dapat ditimbulkan stresor eksternal dan internal. Contoh stressor eks-ternal adalah lingkungan fisik yang tidak menyenangkan seperti bau sampah ataupun lingkungan psikologik tidak menyenangkan seperti relasi rumah tangga yang buruk. Contoh stresor internal ialah nyeri fisik se pada kanker, ataupun ketidakpuasan psikologik seperti merasa gagal.

5. Stress akut menebabkan efek kronotropik dan inotropik positif pada jantung, serta menyebabkan konstriksi arteri.

6. Stres kronik dapat menumpulkan respon sistem imun terhadap infeksi tertentu seperti TBC, dan infeksi virus, ataupun mencetuskan peningkatan produksi faktor imun lokal seperti sitokin.

7. Kegagalan beradaptasi berkaitan dengan onset depresi atau anxietas.

8. Stress kronik akan mempercepat dan memperluas metastasis kanker

9. Beragam prosedur yang berkaitan dengan sistem imun seperti pemberian obat anti kanker, anti-inflamasi, dan transplantasi jaringan harus dilakukan mengacu pada ritme Sirkadian, suatu ritme 24 jam yang mengatur tingkat minimalmaksimal semua fungsi fisiologik.

10. Pendekatan

psikoneuroimunologi dapat digunakan untuk pencegahan atau memperbaiki prognosis penyakit keganasan dan degeneratif, memperbaiki prognosis penyakit infeksi kronik, serta mengefisienkan prosedur transplantasi jaringan.

\section{KEPUSTAKAAN}

1. Berczi and Szentivanyi (2003) NeuroImmune Biology, Elsevier, ISBN 0-444-50851-1 (Written for the highly technical reader).

2. Chrousos, G. P. and Gold, P. W. (1992). The concepts of stress and stress system disorders. Overview of physical and behavioral homeostasis. JAMA 267 (Mar 4), 1244-52.

3. Andersen, B. L., KiecoltGlaser, J. K., and Glaser, R. (1994). A biobehavioral model of cancer stress and disease course. American Psychologist 49(5), 389-404.

4. Cohen, S., Tyrrell, D. A., and Smith, A. P. (1991). Psychological stress and susceptibility to the common cold. The New England Journal of Medicine 325(9), 606-12.

5. "Biological Rhythms and Human Adaptation to the Environment". US Army Medical Research and Materiel Command (AMRMC), US Army Research Institute of Environmental Medicine, 2006.

6. "Biorhythm experiment management plan", NASA, Ames Research Center. Moffett Field, 1983.

7. Brustolim D, Ribeiro-dosSantos R, Kast RE, Altschuler EL, Soares MB. "A new chapter opens in anti-inflammatory 
treatments: the antidepressant bupropion lowers production of tumor necrosis factor-alpha and interferon-gamma in mice." Int Immunopharmacol. 2006 Jun;6(6):903-7.

8. Covelli V, Passeri ME, Leogrande D, Jirillo E, Amati L. Drug targets in stress-related disorders. Curr Med Chem. 2005;12(15):1801-9.

9. Cohen, S. and Williamson, G. M. (1991). Stress and infectious disease in humans. Psychological Bulletin 109(1), 5-24.

10. Diamond M, Kelly JP, Connor TJ. "Antidepressants suppress production of the Th1 cytokine interferon-gamma, independent of monoamine transporter blockade". Eur Neuropsychopharmacol. 2006 Oct;16(7):481-90.

11. Elenkov IJ, Iezzoni DG, A, Harris AG, Chrousos GP. "Cytokine dysregulation, inflammation and well-being". Neuroimmunomodulation. 2005;12(5):255-69.

12. Michael Irwin, Kavita Vedhara (2005). Human

Psychoneuroimmunology. Oxford University Press. ISBN 978-0198568841.

13. Glaser, R. and Kiecolt-Glaser, J. K. (1994). Handbook of Human Stress and Immunity. San Diego: Academic Press.

14. Goodkin, Karl, and Adriaan P. Visser,
Psychoneuroimmunology:

Stress, Mental Disorders, and Health, American Psychiatric Press, 2000, ISBN 0-88048171-4, technical.

15. Herbert TB, Cohen S. Stress and immunity in humans: a meta-analytic review. Psychosom Med. 1993; 55: 364-379.

16. Kiecolt-Glaser, J. K. and Glaser, R. (1999). Psychoneuroimmunology and cancer: fact or fiction? European Journal of Cancer 35, 1603-7.

17. Kubera M, Lin AH, Kenis G, Bosmans E, van Bockstaele D, Maes M. "Anti-Inflammatory effects of antidepressants through suppression of the interferon-gamma/interleukin10 production ratio." $\mathrm{J}$ Clin Psychopharmacol. 2001 Apr; 21(2):199-206.

18. Papanicolaou DA, Wilder RL, Manolagas SC, Chrousos GP. The pathophysiologic roles of interleukin-6 in human disease. Ann Intern Med 1998; 128: 127-37.The Pathophysiologic Roles of Interleukin-6 in Human Disease Annals of Internal Medicine 15 January 1998 | Volume 128 Krisis 2 | Pages 127-137.

19. Pert CB, Ruff MR, Weber RJ, Herkenham M. Neuropeptides and their receptors: a psychosomatic network. J Immunol. 1985 Aug;135(2 Suppl):820s-826s. 
20. $\mathrm{R}$ Ader and N Cohen. Behaviorally conditioned immunosuppression.

Psychosomatic Medicine, Vol 37, Krisis 4 333-340.

21. Ransohoff, Richard, et al (eds), Universes in Delicate Balance: Chemokines and the Nervous System, Elsevier, 2002, ISBN 0444-51002-8.

22. Robert Ader- Robert Ader Papers on Psychoneuroimmunology.

23. Robert Ader, David Nicholas L. Felten, Cohen, Psychoneuroimmunology, 4th edition, 2 volumes, Academic Press, (2006), ISBN 0-12088576-X.

24. Ebert, D., K.P. Ebmeier, T. Rechlin, and W.P. Kaschka, "Biological Rhythms and Behavior", Advances in Biological Psychiatry. ISSN 0378-7354.
25. Ernest Lawrence Rossi, David Lloyd (1992). Ultradian Rhythms in Life Processes: Inquiry into Fundamental Principles of Chronobiology and Psychobiology. SpringerVerlag Berlin and Heidelberg GmbH \& Co. K. ISBN 9783540197461.

26. Gibertini, M.; Graham C., Cook M.R. (1999). "Self-report of Sirkadian type reflects the phase of the melatonin rhythm". Biol psychol. 50 (1): 19-33.

27. Hayes,

D.K. (1990). Chronobiology: Its Role in Clinical Medicine, General Biology, and Agriculture. John Wiley \& Sons. ISBN 9780471568025.

28. Leon Kreitzman; Russell G. Foster (2004). Rhythms of life: the biological clocks that control the daily lives of every living thing. New Haven, Conn: Yale University Press. ISBN 0300-10969-5. 